\title{
About the postponement of clinical discharges from an Integrated Continuous Care Unit (UCCI) for non-clinical reasons: nurses perception study
}

\author{
Prorrogações dos internamentos em Unidades de Cuidados Continuados Integrados por \\ motivos não-clínicos: a percepção de profissionais desaúde sobre factores sociais no processo \\ das altas
}

\author{
M. Carolina Monteiro ${ }^{1 *}$, Osvaldo santos ${ }^{2}$, Maria do Céu Costa ${ }^{2}$ \\ ${ }^{1}$ Instituto de Segurança Social IP, Lisboa, Portugal \\ ${ }^{2}$ CBIOS, Faculdade de Ciências e Tecnologias da Saúde, Universidade Lusófona, Campo Grande 376, 1649-024 Lisboa, \\ PORTUGAL \\ Email: mcarolinamonteiro@sapo.pt
}

\begin{abstract}
*Project developed under the Integrated Continous Care Master Course (3rd Ed) from Universidade Lusófona
*Projecto desenvolvido no âmbito do Curso de Mestrado em Cuidados Continuados Integrados (3 Ed) da Universidade Lusófona
\end{abstract}

\begin{abstract}
This study investigates the perception of health professionals in Continuous Care Units (UCCI) regarding the occurrence (or none) of extension of clients' hospitalization for non-clinical reasons. The group was selected considering their proximity and continuous intervention in supporting the clinical discharges when declared by the physician. This is an exploratory study with a quantitative approach. In methodological terms, a self-completed questionnaire constructed with multiple-choice questions was used. This randomized, convenience sample population included 20 responding nurses. Results show the perceived predominance of family-order factors: 60 $\%$ of the nurses referred to poor or totally absent family support of users or its total absence (45\%). Following, perceived factors are economic reasons $(29 \%)$, including insufficient income $(85 \%)$, institutional reasons $(29 \%)$ for lack/absence of social responses $(50 \%)$, and very close figures for the limited ability of institutions to receive users coming from the UCCI network (45\%). Major structural reasons (65\%) are poor housing conditions and physical barriers to mobility (55\%). To contribute with appropriate solutions to the emerging scenario, this study should be further developed and applied to all nationwide UCCI to reflect and anticipate intervention strategies in continuous care.
\end{abstract}

Keywords: nursing, continuous care, internment extension, clinical discharge postponement, non-clinical

\begin{abstract}
Resumo
O presente estudo tem por objetivo conhecer a percepção dos profissionais de saúde quanto à existência, de factores não-clínicos que se revelem como obstáculos à concretização das altas, nas Unidades de Cuidados Continuados Integrados (UCCI), e que contribuam para o aumento do número de internamentos prorrogados, após alta clínica. Seleccionou-se o grupo dos enfermeiros considerando a sua intervenção contínua e de proximidade para apoio na alta, quando declarada pelo médico. Trata-se de um estudo exploratório, qualitativo, utilizando um questionário auto-preenchido, com perguntas de resposta múltipla, aplicado a uma amostra de conveniência, aleatória, composta por 20 enfermeiros. Nos resultados predominam factores de ordem familiar: $60 \%$ refere o insuficiente ou mesmo a total ausência de qualquer suporte familiar $(45 \%)$. Seguem-se motivos económicos (29 \%), nomeadamente a insuficiência de rendimentos (85\%), motivos institucionais (29\%) por inexistência/ ausência de respostas sociais $(50 \%)$ e, muito próxima, a limitada capacidade das instituições para receberem utentes da REDE (45 \%). Os motivos estruturais são para a maioria a ausência de condições habitacionais (65 $\%)$ e as barreiras físicas à mobilidade (55\%). Visando contribuir para soluções adequadas ao cenário emergente, aconselha-se o aprofundamento deste estudo, aplicando-o a todas as UCCI do país, de modo a reflectir e antecipar as estratégias de intervenção em cuidados continuados.
\end{abstract}

Palavras-chave: enfermeiros, cuidados continuados, prorrogação de internamento, protelamentos de altas clínicas, motivos não clínicos 


\section{Introduction}

Portugal, like most of the developed or developing countries, observes major demographic changes resulting from the sharp and progressive aging of the population $^{[1,2,3]}$. One of the factors associated with human aging is the increase in average life expectancy of the population ${ }^{[4]}$. Accordingly, it was found that, between 2000 and 2008, there was an increase of 2.7 years for men, with an average of 75.7 years old, and 1.9 years for females, which was equivalent to an average of 82.2 years old ${ }^{[5]}$. In 2011, the average life expectancy for men was indicated as 76.7 years and 82.6 years for women ${ }^{[6]}$. Within this demographic context, the number of people suffering from addiction due to chronic and disabling diseases naturally increases, resulting in increased demand for answers on the health and social level and integrated ${ }^{[7,8]}$ answers. Inadequacies of social and health responses have been evident in our country regarding the sociodemographic reality, particularly with regard to the low value of social security benefits (including renovations and additions) and the deficiencies in the health system (expressed, for example, in terms efficiency in response time and accessibility to health care $)^{[9]}$.

These demographic changes have recently induced a new approach within existing social policies, seeking strategies that respond effectively to this new corporate structure $^{[10,11]}$. These strategies have led to increased responses in the social area and the creation of a new response in health to include the social aspect: an integrated continuum of care.

Until 2006, there were no connective responses between the provision of care for patients qualified as acute in situations of illness with severe symptomatic manifestation and continuation of care without the need for hospitalization in acute units, such that hospitals were the only answer/alternative for people who found themselves in a situation of dependent care ${ }^{[12]}$. These excessive and unnecessary stays in hospitals are associated with a negative level of health security (users exposed to outbreaks of infection and other hostile elements to recovery), and negatively impacts both the level of efficiency and responsiveness of health facilities in acute situations and the macroeconomics of health care ${ }^{[13,14]}$. This is the knowledge of the state and was recognized in the Hospital Reform 2011 Report, which highlights the lack of beds available for new admissions of patients requiring continuing care, which is referred to as the reason for the inappropriate stay of acute patients in hospitals for several decades ${ }^{[15]}$.

Currently there are a wide range of responses both in

\section{Introdução}

Portugal, tal como a maioria dos países desenvolvidos ou em vias de desenvolvimento, assiste a grandes alterações demográficas resultantes do acentuado e progressivo envelhecimento da sua população ${ }^{[1,2,3]}$. Um dos factores associado ao envelhecimento humano é o aumento da esperança média de vida das populações ${ }^{[4]}$. Nesse sentido, verificou-se que, entre o ano de 2000 e o ano de 2008, houve um aumento de 2,7 anos para os homens, situando a média nos 75,7 anos, e de 1,9 anos nas mulheres, o que equivaleu a uma média de $82,2 \operatorname{anos}^{[5] .}$ Em 2011, a esperança média de vida indicada para os homens era de 76,7 anos, e para as mulheres 82,6 anos ${ }^{[6]}$. Neste contexto demográfico, surge naturalmente o aumento de pessoas em situação de dependência, devido a doenças crónicas e incapacitantes, resultando o aumento da procura de respostas na área da saúde e ao nível social, e em respostas integradas ${ }^{[7,8]}$. Tem sido evidente a desadequação das respostas sociais e de saúde no nosso país relativamente à realidade sociodemográfica, nomeadamente no que respeita ao baixo valor das prestações sociais (incluindo reformas e complementos) e as deficiências no sistema de saúde (expressa, por exemplo, em termos da eficácia no tempo de resposta e da acessibilidade a cuidados de saúde) ${ }^{[9]}$. Estas alterações demográficas resultaram, recentemente, numa nova abordagem das políticas sociais existentes, perspectivando estratégias que respondam de forma eficaz a esta nova estrutura societária ${ }^{[10,11]}$. Dessas estratégias emergiram o aumento de respostas na área social e a criação de uma nova resposta na área da saúde que contempla a vertente social: os cuidados continuados integrados.

Até 2006, não existiam respostas de ligação entre a prestação de cuidados de doentes qualificados como agudos, em situação de enfermidade com manifestação sintomática grave, e a continuação de cuidados sem necessidade de internamento em unidades de agudos. As unidades hospitalares constituíam, assim, a única resposta/alternativa para as pessoas que se encontravam em situação de dependência de cuidados ${ }^{[12]}$. Estas permanências excessivas e desnecessárias nas unidades hospitalares estão associadas a impactos negativos ao nível da segurança de saúde (utentes expostos a focos de infecção e outros elementos hostis à sua recuperação), ao nível da eficiência e capacidade de resposta por parte das unidades de saúde, a situações agudas, e ao nível macro económico da prestação de cuidados de saúde ${ }^{[13,14]}$.

Esta situação é do conhecimento do Estado e reconhecida no relatório de Reforma Hospitalar de 2011, que 
the health and the social area, primarily intended to ensure care and promote the well-being of people in situations of dependent care, whether permanent or transitory. In the social area, there was an enlargement of the ability to support the elderly and/or in situations of dependency through Residential Structures for the Elderly (ERPI) and entities providing home support services persons (SAD- Serviços de Apoio Domiciliário) [16]. According to data registered in the Social Charter of the Ministry of Labour and Social Solidarity (MTSS), for the year $2012^{[10,17]}$ there were 2093 ERPI (Estruturas Residenciais para Idosos/ Residential Structures for Seniors), with capacity for 79,997 users and 2566 SAD provider entities with the capacity to provide service to 96,785 users ${ }^{[17]}$. In health, the National Network for Integrated Continuous Care (RNCCI - Rede Nacional de Cuidados Continuados Integrados, abbreviated as NET) began operating in 2006 and came to tackle the problem of inappropriate use of hospitalization by addressing needs arising from an aging population in a health and social nature ${ }^{[17]}$. The NET has in its constitution Inpatient Units (UCCI), receiving clients who need specific care, maintenance/rehabilitation so that they can later return home ${ }^{[4,18,19]}$. The UCCI are comprised of multidisciplinary teams and act according to a multidisciplinary intervention model that incorporates aspects of health, social, and economic state of users [20,21]. Between December 2008 and December 2012, NET had signed contract for a total of 3041 new hospital beds, resulting in a total of 5911 beds ${ }^{[14,21]}$.

Regarding the UCCI, the postponement of the clinic discharges for non-clinical reasons hinders achievement of pre-agreed targets with the Ministry of Health / Ministry of Solidarity and Social Security in terms of compliance with clinic discharge dates, preventing the entry of new users. This is a troubling situation, considering that the population is growing older and more dependent. The RNCCI 2013 Final Report for the Implementation and Monitoring refers to the lack of jobs in nursing homes, particularly in IPSS - Private Institutions of Social Solidarity - as one of the factors that block the maximum numbers of integrated patients in UCCI. Hence, the stranglehold at the NET level is promoted, which in turn has implications at the hospital level, notably by blocking the patients with clinical discharge admission criteria at $\mathrm{UCCI}^{[22]}$. A previous study conducted in a hospital unit found that in $98.8 \%$ of cases, the prolongation of hospitalization was due to problems of socio-familial context ${ }^{[23]}$.

This is a reality that nurses face daily. Not only they are confronted with the admission of new clients in the units whose reference is based on inadequate typolo- alerta para a falta de camas disponíveis para novos internamentos de doentes com necessidade de cuidados continuados, sendo este referido como o motivo da permanência inapropriada de doentes nos hospitais de agudos, durante várias décadas ${ }^{[15]}$.

Actualmente existe um variado leque de respostas tanto na área da saúde como na área social, que têm por objectivo principal assegurar cuidados e promover o bem-estar das pessoas que se encontram em situação de dependência de cuidados, seja esta definitiva ou transitória. Na área social verificou-se um alargamento da capacidade de apoio a pessoas idosas e/ou em situação de dependência, das Estruturas Residenciais para Idosos (ERPI) e das entidades prestadoras de Serviços de Apoio Domiciliário (SAD $)^{[16]}$. Segundo os dados registados na Carta Social do Ministério do Trabalho e Solidariedade Social (MTSS), relativamente ao ano $2012^{[10,17]}$ havia 2093 ERPI, com capacidade para 79 997 utentes e 2566 entidades prestadoras de SAD com capacidade de prestar serviço a 96785 utentes $^{[17]}$. Na área da saúde, a Rede Nacional de Cuidados Continuados Integrados (REDE) entrou em funcionamento em 2006 e veio debelar o problema da utilização inapropriada do internamento hospitalar, colmatando necessidades na área de saúde e de natureza social, decorrentes do envelhecimento populacional ${ }^{[17]}$. A REDE tem na sua constituição Unidades de Internamento (UCCI) que recebem utentes que necessitam de cuidados específicos, de manutenção/reabilitação para que estes possam posteriormente regressar ao domicílio ${ }^{[4,18,19]}$. As UCCI atuam segundo um modelo de intervenção multidisciplinar que contempla as vertentes da saúde, social e económica dos utentes e são compostas por equipas multidisciplinares ${ }^{[20,21]}$. Entre dezembro de 2008 e dezembro de 2012, a REDE contratualizou um total de 3041 camas de internamento, perfazendo um total de 5911 camas $^{[14,21]}$

No que se refere às UCCI, o adiamento das altas por motivos não-clínicos promove a não concretização dos objectivos pré-acordados com o Ministério da Saúde / Ministério da Solidariedade e Segurança Social, em termos de cumprimento de datas de alta clínica, o que inviabiliza a entrada de novos utentes. Situação algo preocupante, considerando que a população está cada vez mais idosa e mais dependente. O Relatório Final de Implementação e Monitorização da RNCCI de 2013 refere a insuficiência de vagas em lares, nomeadamente em IPSS, como um dos factores que bloqueiam a alta de doentes integrados nas UCCI. Promove o estrangulamento ao nível REDE, que por sua vez tem repercussões a nível hospitalar, nomeadamente através do bloqueio da alta de doentes com critérios de admissão em UCCI ${ }^{[22]}$. Num estudo realizado em unidade hospitalar concluiu-se que, em $98,8 \%$ dos casos, o prolongamento do internamento se devia a problemas do âmbito sociofamiliar ${ }^{[23]}$.

Esta é uma realidade com que os profissionais de en- 
gies, as when beginning the process of preparing the clinical discharge they verify that users (patients) are isolated and there is no one who can organize this planning properly, and/or the nurses are questioned by users for their excessive stay in healthcare facilities ${ }^{[22]}$. In this context, it is undisputed that nurses have an important role, by the direct intervention with patients ${ }^{[24]}$, as well as a key role in monitoring the process of clinical discharge, being the professionals closer to the inpatients, and those who make liaison between the patient and the remaining technical staff ${ }^{[25]}$.

The aim of this study was to assess the UCCI nurses' perception of the existence of non-clinical social factors that stand as barriers to clinical discharges of UCCI users. This study aims to deepen understanding of the topic to better appreciate the problem, and contribute to a widespread and deep reflection that can lead to solutions to mitigate the adverse effects of clinical discharge postponements.

\section{Methods}

This is an exploratory study with a quantitative approach. Sampieri ${ }^{[26]}$ argues that exploratory studies usually take place when the main objective is to study subjects little studied or expand existing studies based on new perspectives. The data collection instrument used was a self-completed questionnaire, constructed based on the literature review of instruments used to identify barriers to clinical discharges in different contexts of care, with the aim of collecting information on the perception of professionals regarding clinical discharges postponements. The questionnaire was constructed with multiple choice questions, in which variables that identified non-clinical reasons were defined. Variables were defined exclusively in social field, and took into account family and economic reasons, as well as factors at the structural and institutional levels. Regarding the construction of the sampling process, it was chosen for convenience from a continuous care unit. All nurses in this unit with direct intervention with patients were invited to participate in the study.

It should be noted that in the preparation of this study, and during the process of research and data collection, universal ethical principles such as the right to freedom of participation and the respect of the willingness of the participants, were all assured through the informed consent and personal data protection procedures. The anonymity and confidentiality of the data was preserved for all the professionals who participated in the study and develop activity at the UCCI. fermagem se deparam diariamente. Não só se vêm confrontados com a admissão de novos utentes nas unidades, referenciados com base em tipologias inadequadas, como quando iniciam processo de preparação de alta verificam que os utentes são isolados e não existe com quem possam organizar esse planeamento, e/ou são questionados pelos utentes quanto à sua permanência excessiva nas unidades de saúde ${ }^{[22]}$. Neste contexto, é indiscutível que os enfermeiros têm um papel relevante, pela sua intervenção direta com os utentes ${ }^{[24]}$, bem como um papel fundamental no processo das altas, por serem os profissionais que estão mais próximo dos doentes, e os que fazem de elo de ligação entre o doente e a restante equipa técnica ${ }^{[25]}$.

O objectivo deste estudo foi aferir a percepção dos enfermeiros de uma UCCI quanto à existência de factores sociais, não clínicos que se apresentam como obstáculos à alta dos utentes das UCCI. Este estudo pretende aprofundar o conhecimento sobre o tema para uma melhor compreensão da problemática, e contribuir para uma reflexão generalizada e mais aprofundada que possa conduzir a soluções para minorar os efeitos adversos.

\section{Métodos}

Trata-se de um estudo exploratório, com uma abordagem quantitativa. Sampieri ${ }^{[26]}$ defende que os estudos exploratórios geralmente se realizam quando o objectivo principal é o de estudar temas pouco estudados ou ampliar estudos já existentes, com base em novas perspectivas. O instrumento de recolha de dados utilizado foi um questionário auto-preenchido, construído com base na revisão de literatura sobre instrumentos utilizados para identificação de obstáculos à alta clínica, em diferentes contextos de cuidados de saúde, com o objectivo de recolher informação sobre a percepção dos profissionais relativamente aos protelamentos de altas clínicas. $\mathrm{O}$ questionário foi construído com perguntas de resposta múltipla, no qual foram definidas variáveis que permitiram a identificação de motivos não clínicos. As variáveis definidas, exclusivamente do âmbito social, consideraram motivos de ordem familiar e económica, estrutural e institucional. Quanto ao processo de construção da amostragem, foi escolhida por conveniência uma unidade de cuidados continuados. Todos os enfermeiros desta unidade, com intervenção direta com os utentes, foram convidados a participar no estudo.

Importa referir que na elaboração deste estudo, e durante o processo de pesquisa e recolha de dados, foram respeitados princípios éticos fundamentais como o direito à liberdade de participação bem como a vontade dos participantes, assim como foram assegurados e respeitados todos os procedimentos que visaram preservar o anonimato dos dados e confidencialidade, de todos os profissionais que participaram e desenvolvem actividade na UCCI. 


\section{Results}

Twenty nurses participated in the study, of which $16 / 20$ elements were female and 4/20 male. The average age was around 26 years. Most participants had been practicing within their professional activities for over two years $(80 \%)$ and working in the unit studied for more than two years $(72 \%)$

Concerning the data compiled, all nurses identified social factors that were considered obstacles to the achievement of the clinical discharge from the UCCI. Although most noted as the main obstacle to social type of existing family support (33\%), importance was also given to economic reasons $(29 \%)$ and institutional responses $(29 \%)$. In relation to structural reasons (Figure $1)$, although these are not present so expressively, they still represent $7 \%$ of the answers given.

\section{Resultados}

Participaram no estudo 20 enfermeiros, dos quais 16 são elementos do sexo feminino e 4 do masculino. A média das idades ronda os 26 anos. A maioria exerce a profissão há mais de 2 anos $(80 \%)$ e trabalham na unidade em estudo há mais de 2 anos (72\%)

Relativamente aos dados apurados todos os enfermeiros identificaram factores de ordem social que são obstáculos para a concretização das altas na UCCI. Apesar de a maioria referir como principal obstáculo social o tipo de suporte familiar existente (33\%), também é dada relevância aos motivos económicos $(29 \%)$ e às respostas institucionais (29\%). Quanto aos motivos estruturais (Figura 1), apesar destes não se apresentarem de forma tão expressiva, representam $7 \%$ das respostas dadas.

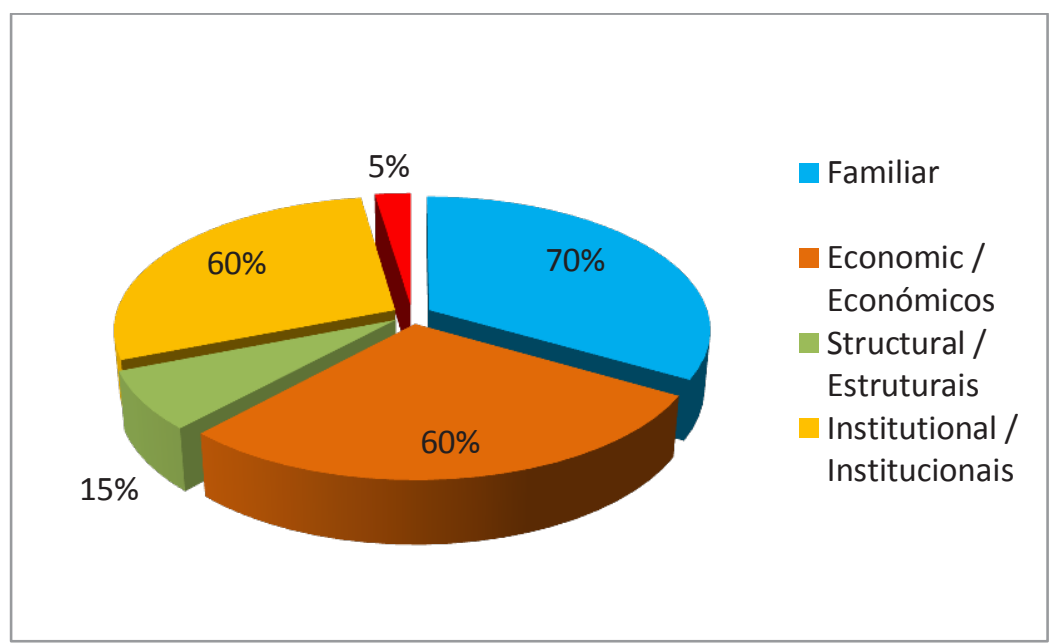

Figure 1/ Figura 1. Social motives as promoters of clinical discharge postponement. Motivos sociais promotores de adiamento de alta clínica.

Relating to family reasons, $60 \%$ of nurses referred to insufficient family support of patients and $45 \%$ referred the absence of any family support as the most relevant factors, $25 \%$ indicated the inadequacy of family support and $15 \%$ considered a complete absence of caregivers (Figure 2).

Among economic reasons referred, insufficient income is the factor most often mentioned ( $85 \%)$ followed infrequent failure of revenue management $(10 \%)$, or patient inaccessibility (10\%) (Figure 3). Additionally, family responsibilities were referred, although this has little significance $(5 \%)$.
Relativamente aos motivos familiares, $60 \%$ dos enfermeiros refere o suporte familiar dos utentes insuficiente e a ausência de qualquer suporte familiar (45\%) como factores mais relevantes, 25 \% indica a inadequação do suporte familiar e $15 \%$ a completa ausência de cuidadores (figura 2).

Dos motivos económicos referidos, a insuficiência de rendimentos é o factor indicado mais frequentemente (85\%) sendo pouco frequente a incapacidade de gestão dos rendimentos $(10 \%)$, ou a sua inacessibilidade (10 $\%$ ) (Figura 3).Também foram referidos os encargos familiares apesar de tal ter sido de forma pouco expressiva $(5 \%)$. 


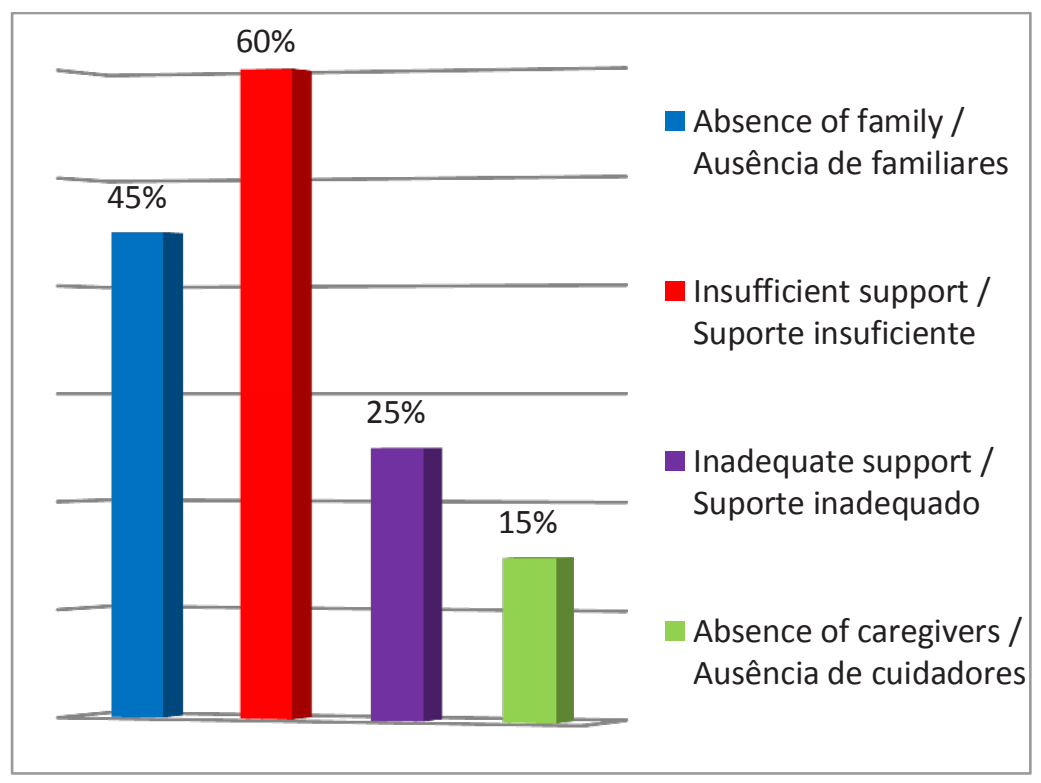

Figure 2/ Figura 2. Social motives related to family reasons.

Motivos sociais de ordem familiar.

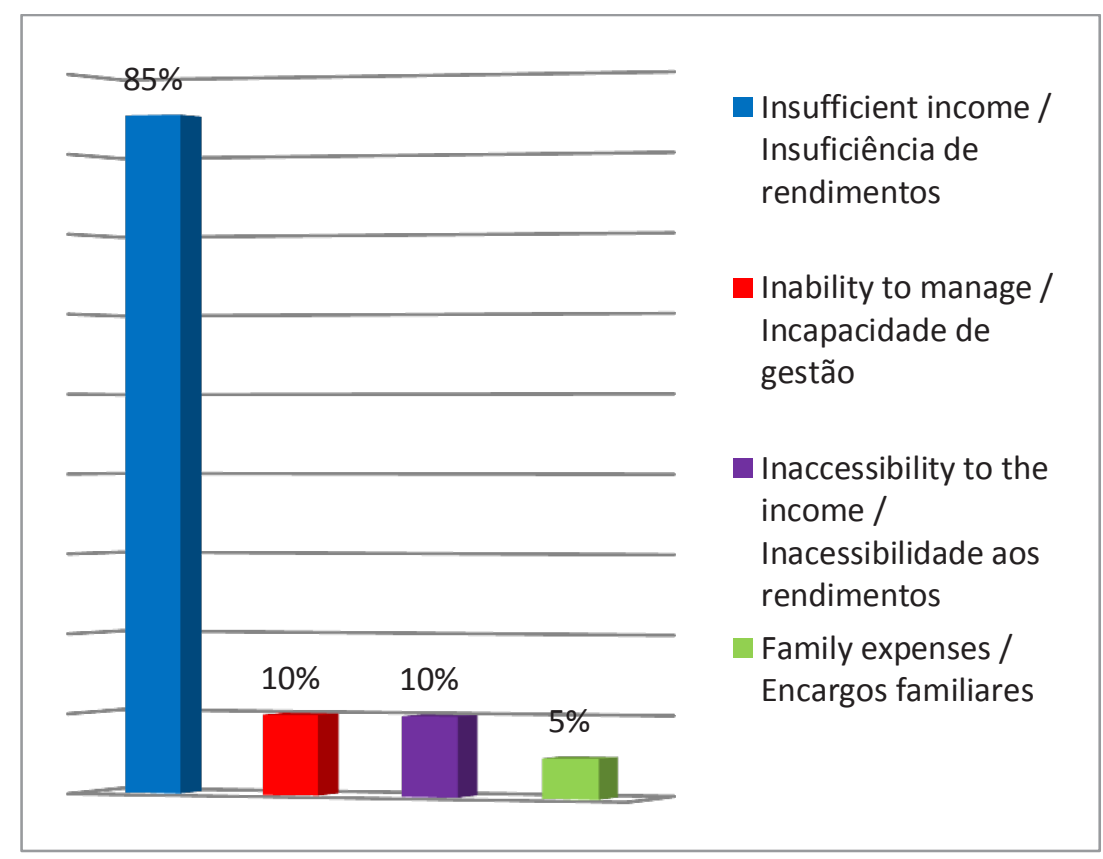

Figure 3/ Figura 3. Social motives of economic order.

Motivos sociais de ordem económica 
As for reasons related to limiting factors of institutional order, the extensions for lack/absence of social responses were most frequently mentioned (50\%), followed by limited institutional capacity for receiving users coming from the NET (45\%). The inadequacy of available responses was considered less impressive $(10 \%)$. The workload of professionals was also seen as a factor influencing the postponement of the clinical discharges (5\%). (Fig. 4)
Quanto aos motivos relacionados com factores limitantes de ordem institucional, as prorrogações por inexistência/ausência de respostas sociais são as mais frequentemente indicadas (50\%), seguindo-se capacidade limitada das instituições para receberem utentes vindos da REDE (45\%). Menos expressiva é considerada a inadequação de respostas disponíveis $(10 \%)$. A carga laboral dos profissionais também foi considerada um factor influenciador do adiamento das altas (5\%). (Fig. 4)

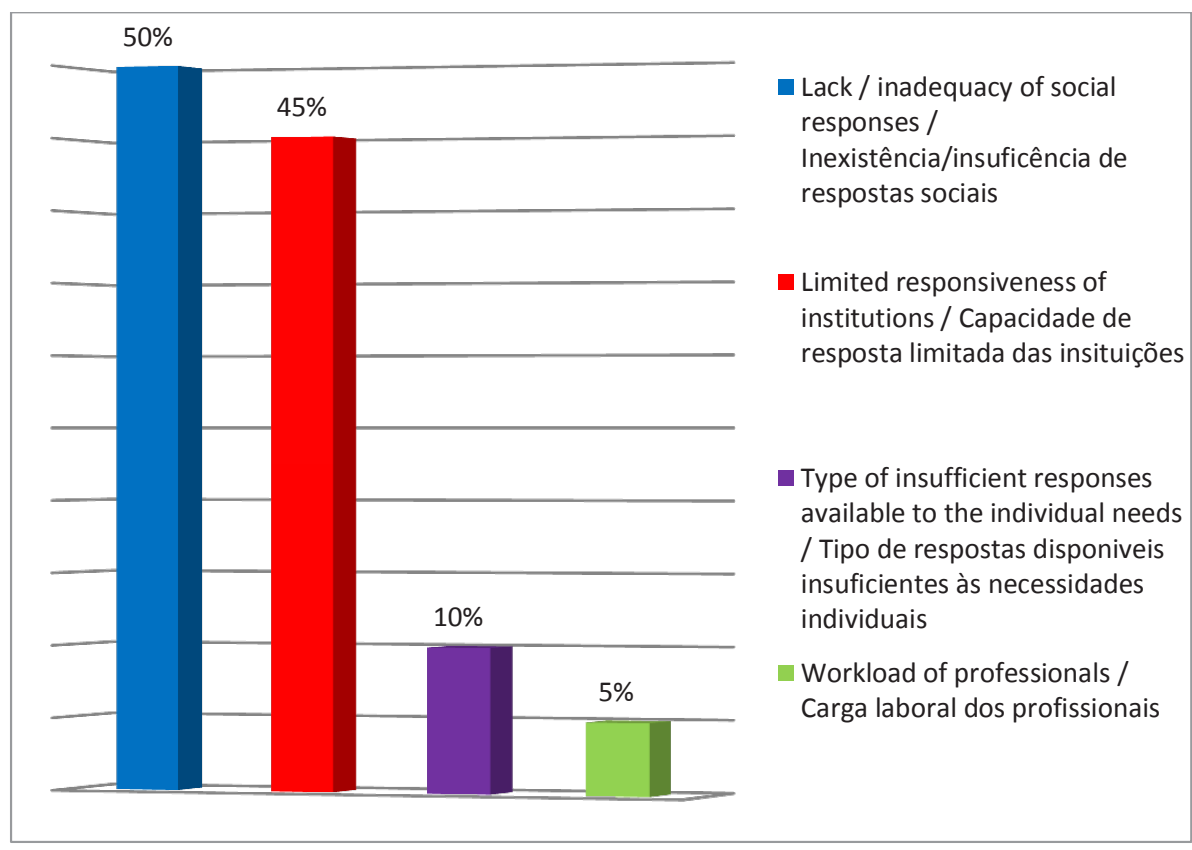

Figure 4/ Figura 4. Social motives of institutional order (in

terms of social responses).

Motivos sociais de ordem institucional (ao nível das

respostas sociais).

Regarding the perception of structural reasons (less frequently reported in general), it can be seen that $65 \%$ of the nurses indicate the absence of housing conditions and $55 \%$ refer to physical barriers to mobility. Only 15 $\%$ indicated the absence of housing and $5 \%$ referred to geographic distance as an obstacle. (Fig. 5)
Quanto à percepção sobre motivos estruturais (menos frequentemente reportadas, no geral), verifica-se que $65 \%$ dos enfermeiros que as indicam salientam a ausência de condições habitacionais e que $55 \%$ referem barreiras físicas à mobilidade. Apenas $15 \%$ indicou a ausência de habitação e 5 \% a distância geográfica. (Fig. 5) 


\section{Discussion}

Portugal is in a seemingly irreversible process of aging, and lacks appropriate state responses to this reality. As Correia ${ }^{[27]}$ notes, this country is one of the least endowed with structures of social support and, above all, health care for dependents and elderly ${ }^{[27]}$ people. The UCCI emerged as a solution to accommodate people who are in a situation of dependency and need for specialized care, but do not require the care of an acutecases unit. These UCCI are composed of multidisciplinary teams in which nurses have an important role in direct intervention with patients.

Nursing professionals deal regularly and very closely with the users of these care units. This allows them to have an adequate perception of the majority of cases where a clinical discharge is not possible, thus identifying the existence of factors that hinder its effectiveness $^{[28]}$.

The 20 nurses participating in this study revealed clearly that, according to their perception, they are able to identify factors of non-clinical nature, associated with social determinants that influence the achievement of clinical discharges of some users.

The results indicate that, for most users, family support is insufficient/inadequate or nonexistent (60\% and $45 \%$, respectively), which may be associated with the known fact that the majority of older persons live alone and may be isolated or have elderly family support ${ }^{[29]}$. In these cases, insufficient income is a very important conditioning element (85\%). Similarly, a study conducted in three central hospitals in Australia revealed that nurses consider that the isolated elderly patients with dementia and/or mental disabilities most constraining for the realization of the clinical discharge ${ }^{[30]}$. Concerning the existence of operational constraints at the level of institutional response, the nurses who participated in the study suggested primarily the lack/ insufficiency and/or limited responsiveness of the institutions concerned for this type of population. These results are understandable when contextualized by the data published on the Social Charter 2011 annual report which stated that in the metropolitan areas of Lisbon and Porto the demand for social responses was greater than the available capacity ${ }^{[15]}$.

The indication of social structural reasons, as a dwelling without basic living conditions (65\%) and the existence of physical barriers to mobility $(5 \%)$ are also factors impeding their return home and, consequently, effecting clinical discharge because, being mostly elderly, they have great mobility limitations. Again with the study in Australia as a reference (op. Cit), our results have several similarities with their results, particu-

\section{Discussão}

Portugal encontra-se num processo aparentemente irreversível de envelhecimento, com insuficiência de respostas estatais adequadas a esta realidade. Tal como Correia $^{[27]}$ refere, é um dos países menos dotados de estruturas de apoio social e, sobretudo, de cuidados de saúde a pessoas dependentes e idosas. As UCCI surgiram como uma solução para acolher as pessoas que se encontram em situação de dependência e com necessidade de cuidados diferenciados, que não necessitavam de cuidados de uma unidade de agudos. Estas UCCI são compostas por equipas multidisciplinares, nas quais a enfermagem tem um papel relevante pela sua intervenção direta com os utentes.

Os profissionais de enfermagem lidam regularmente e de forma muito próxima com os utentes. Esta situação permite-lhes ter uma percepção adequada da maioria dos casos em que não é possível concretizar a alta clínica, identificando a existência de factores que impedem a sua efetivação ${ }^{[28]}$.

Os 20 enfermeiros participantes neste estudo revelaram, de forma clara que, de acordo com a sua percepção, identificam factores de natureza não-clínica, associados a determinantes sociais que condicionam a concretização das altas de alguns utentes.

Os resultados obtidos indicam que, para a maioria dos utentes, o suporte familiar é insuficiente/inadequado ou inexistente $(60 \%$ e $45 \%)$, o que poderá estar associado ao facto conhecido de a maioria da população idosa viver só e estar isolada ou ter um suporte familiar igualmente idoso ${ }^{[29]}$. Nestes casos a insuficiência de rendimentos é um elemento condicionador de grande relevância $(85$ \%). No mesmo sentido, um estudo realizado em 3 hospitais centrais, na Austrália, revelou que enfermeiros consideram que os doentes idosos isolados, com demências e/ou deficiências mentais, são os que mais constrangimentos sociais apresentam para a concretização da alta ${ }^{[30]}$.

Quanto à existência de constrangimentos operacionais ao nível de respostas institucionais, os enfermeiros que participaram no estudo aqui descrito sugerem, principalmente, a inexistência/insuficiência e/ou a capacidade limitada de resposta por parte das instituições vocacionadas para este tipo de população. Estes resultados são entendíveis quando contextualizados pelos dados publicados no relatório anual da Carta Social de 2011, onde é referido que, nas zonas metropolitanas de Lisboa e Porto, a procura de respostas sociais foi superior à capacidade disponível ${ }^{[15]}$.

A indicação da existência de motivos sociais de carácter estrutural, como uma habitação sem condições básicas de habitabilidade ( $65 \%)$ e a existência de barreiras físicas à mobilidade (5\%) são igualmente factores impeditivos de regresso ao domicílio e, consequentemente, de efectivar a alta clínica pois, sendo a maioria idosos, apresentam grandes limitações de mobilidade. Ainda 
larly when nurses refer to the common constraints in the management of beds due to the waiting time, and lack of community support equipment, namely the lack of beds in nursing homes ${ }^{[30]}$.

The present study is also in line with other studies, such as Grimmer et al ${ }^{[30]}$ because of the social factors identified as affecting discharges for non-clinical reasons: family, economic, institutional and structural. However, we cannot fail to mention that all the variables included in each of the studies should be taken into account as they may be, alone or together with other factors, conditioning elements of some of the discharges of some users. Note that the work of Grimmer et al [30] also aimed to identify factors that may be barriers to improving the quality of planning of discharges in acute hospitals, conditioning its effectiveness, as perceived by health professionals, including nursing teams.

The characterization of this scenario in the UCCI and the analysis of its impact in relation to hospital operation lack a systematic identification of social cases in the global NHS ${ }^{[23]}$.

As an exploratory study with regard to the high UCCI, this study has some limitations in the validation and extrapolation of the findings, mainly because it is a too recent area lacking bibliographical documentation and scientific approach, although there are some studies reported on the perceptions of nurses regarding postponement of discharges at hospital level. However, the entire process of searching for information is an asset in the deepening of the theme. The conclusions were based on a study of comparative support in a hospital context in which a cautious approach was required, in fervent effort to avoid biases.

\section{Conclusions}

From the results, it was concluded that the postponement of the discharges is conditioned by social reasons. Confronted with the issue, the nurses showed an understanding of the situation and highlighted, on their perception, as constraints the economic factor, namely the insufficient income, followed by low economic income of the household, as well as the low value of the pensions or financial burden of monthly fixed expenses, such as maintenance costs, health and livelihood. Asked about the existence of social reasons at the family level, most indicated the inadequacy and/or lack of family support, and the age of their companions or the death of them, as factors contributing to this condition. tendo presente o estudo na Austrália (op. cit) os seus resultados, apresentam várias semelhanças nos resultados apresentados, nomeadamente em que os enfermeiros referem os condicionalismos comuns na gestão de camas devido ao tempo de espera, por falta de equipamentos de suporte comunitário, nomeadamente a falta de camas em equipamentos do tipo lares ${ }^{[30]}$.

Salientam-se, assim, no presente estudo como no de Grimmer et $\mathrm{a}^{[30]}$ os factores identificados como condicionantes das altas por motivos não-clínicos serem factores de ordem social: familiar, económica, institucional e estrutural. No entanto, não podemos deixar de referir que todas as variáveis incluídas em cada um dos estudos devem ser tidas em conta pois podem ser, isoladamente ou em conjunto com outros factores, elementos condicionadores das altas de alguns utentes. De notar que o trabalho de Grimmer et al ${ }^{[30]}$ também teve por objectivo identificar factores que podem constituir barreiras à melhoria da qualidade do planeamento das altas em hospitais de agudos, condicionando a sua eficácia, segundo a percepção dos profissionais de saúde, incluindo equipas de enfermagem.

A caraterização deste cenário nas UCCI e a análise do seu impacto em relação com o funcionamento das unidades hospitalares carece de uma identificação sistemática dos casos sociais no $\mathrm{SNS}^{[23]}$.

Por tratar-se de um estudo exploratório, apesar de haver alguns estudos sobre as percepções dos enfermeiros quanto aos protelamentos ao nível hospitalar, no que se refere às altas nas UCCI, e, ainda, por ser uma área ainda muito recente a documentação bibliográfica e científica é inexistente, este estudo tem algumas limitações na validação e extrapolação das suas conclusões. Contudo, todo o processo de pesquisa de informação constitui uma mais-valia no aprofundamento do tema. As conclusões apresentadas tiveram como base de suporte comparativo um estudo efectuado em contexto hospitalar pelo que foi necessário efectuar uma abordagem cautelosa, tentando ao máximo evitar enviesamentos.

\section{Conclusões}

Dos resultados apurados, concluiu-se que o protelamento das altas é condicionado por motivos sociais. Confrontados com o tema, os enfermeiros mostraram conhecer situação e destacaram como condicionantes na sua percepção, o factor económico, nomeadamente a insuficiência de rendimentos, seguido do baixo rendimento económico do agregado familiar, o baixo valor das pensões ou o peso orçamental das despesas fixas mensais, tal como despesas de manutenção, de saúde e de subsistência. Inquiridos sobre a existência de motivos sociais ao nível familiar, a maioria indicou a insuficiência e/ou a ausência de suporte familiar dos utentes, sendo a idade avançada dos companheiros ou pelo falecimento dos mesmos, um dos factores que mais 
For structural reasons, the majority refer to physical barriers as significant constraints on users' mobility in housing elements, followed by the lack of basic conditions of habitability (including health conditions and comfort).

The institutional reasons for clinical discharge postponement are almost unanimously referred through the absence/lack of social responses and the limitation of the institutions in their responsiveness. That means there is limited capacity of institutions which leads to lack of vacancies for new admissions, owing to the growing demand. This reality is even assumed in RNCCI report, March / [22] that "In the social area, the lack of beds in nursing homes creates blockages to patient discharge from the base of the Network, i.e. the Long Term Units and thereafter up to hospitals. Any bottleneck in the social network and RNCCI is reflected upstream, i.e. at hospital level, blocking the discharge of patients who need the same ".

Given the observed results, and taking into account the reality of an aging population and the need for a prospective management of continuing care, it is considered important to the continued study of this topic to perform an investigation covering all UCCI within the national territory in order to promote a global reflection and seek to create joint strategies to tackle this issue.

\section{Conflict of Interest}

The authors declare that they have no financial or personal relationships that could be construed as having potential conflicts of interest. contribui para esta condicionante. Quanto aos motivos estruturais, a maioria refere as barreiras físicas, enquanto elementos condicionantes à mobilidade dos utentes na habitação, seguindo-se a inexistência de condições básicas da habitabilidade (nomeadamente condições de salubridade e conforto).

No que se refere aos motivos institucionais, é quase unânime a referência à inexistência/ausência de respostas sociais e a limitação das instituições na sua capacidade de resposta. Ou seja: a capacidade limitada das instituições leva à inexistência de vagas para novas admissões, pela crescente procura. Esta realidade é assumida no relatório de RNCCI, de Março/2013 que "Na área social, a carência de camas em lares cria bloqueios à alta de doentes provenientes da base da Rede, ou seja das Unidades de Longa Duração e a partir daí até aos Hospitais. Qualquer estrangulamento na rede social e na RNCCI reflecte-se a montante, ou seja a nível hospitalar, bloqueando a alta de doentes que das mesmas necessitem" ${ }^{[22]}$.

Face aos resultados observados, e tendo em conta a realidade do envelhecimento populacional e necessidade de uma gestão prospectiva dos cuidados continuados, considera-se relevante a continuação do estudo deste tema, numa investigação que abranja todas as UCCI do território nacional, de modo a reflectir e procurar a criação de estratégias conjuntas que possam fazer face a esta questão.

\section{Conflito de Interesses}

Os autores declaram que não têm relações financeiras ou pessoais que possam ser entendidas como apresentando potenciais conflitos de interesse. 


\section{References / Referências}

[1] Simões, M.; Salgueiro, N.\& Rodrigues, M. (2012). Cuidar em humanitude: estudo aplicado em cuidados continuados. Revista de Enfermagem de Referência, III Série- $n^{\circ} 6$, Mar.2012, pp.81-93.

[2] Paschoal, S. M. (2000). Qualidade de Vida do Idoso: Elaboração de um instrumento que privilegia sua opinião. Dissertação de mestrado apresentada à Faculdade de $\mathrm{Me}$ dicina da Universidade de S. Paulo, para obtenção do grau de mestre, orientada por Júlio Litvoc. São Paulo.

[3] Carrilho, M. J. \& Patrício, L. (2010). A situação demográfica recente em Portugal. INE Ed. Revista Estudos Demográficos, $\mathrm{n}^{\circ} 48$, pp. 101-145.

[4] Ferreira, P. L. et al. Tradução e validação para a língua portuguesa do questionário de planeamento da alta (PREPARED). Revista de Enfermagem de Referência [versão electrónica]. 2011, vol. ser III, n.5, pp. 121-133. ISSN 0874-0283.

[5] Carrilho, M J. \& Gonçalves, C. (2006). Envelhecimento crescente mas espacialmente desigual. INE, Ed.. Revista Estudos Demográficos, $n^{\circ} 40$, pp. 21-37.

[6] INE. (2009). Projecções de população residente em Portugal 2008-2060. ISSN 16457633, ISBN 978-989-25-0037-9. Acedido a 12 de Março de 2014 em http://www.ine. $\mathrm{pt} / \mathrm{xportal} / \mathrm{xmain}$ ?xpid=INE\&xpgid=ine publicacoes\&PUBLICACOESpub_boui $=6$ $5944632 \&$ PUBLICACOESmodo $=2 \& x$ lang $=\mathrm{pt}$

[7] Giddens, A. (2000). Sociologia. Lisboa: Fundação Calouste Gulbenkian

[8] Araújo, I.; Paul, C. \& Martins, M.. Cuidar no paradigma da desinstitucionalização: a sustentabilidade do idoso dependente na família. Revista de Enfermagem de referência. III Série-nº 2, Dez.2010, pp. 45-53

[9] Barreto, A. (2002). Mudança Social em Portugal 1960/2000. Lisboa: Instituto de Ciências Sociais da Universidade de Lisboa. Wp 6-02; Outubro 2002. Acedido a 18 de Março de 2014 em http://www. fcsh.unl.pt/docentes/luisrodrigues/textos/ Mudan $\%$ C3\%A7a\%20Social\%20em\%20 Portugal $\% 20$ Ant $\%$ C3\%B3nio\%20Barreto. pdf

[10] UMCCI. (2012). Relatório de monitorização do desenvolvimento e da actividade da Rede Nacional de Cuidados Continuados Integrados (RNCCI) - $1^{\circ}$ Semestre de 2012 Julho. [versão electrónica]. Acedido a 2 Março 2014 em http://www.rncci.min-saude.pt/ SiteCollectionDocuments/rev relatorio 1 semestre_2012.pdf
[11] Carrilho, MJ. \& Patrício, L. (2007). A Situação demográfica recente em Portugal. INE Ed. Revista Estudos Demográficos, nº46, pp. 59-107.

[12] Campos, AC. de (2008). Reformas da Saúde. Coimbra, Almedina

[13] Dias, A. \& Santana, S. (2009). Cuidados integrados: um novo paradigma na prestação de cuidados de saúde. Rev. Portuguesa e Brasileira de Gestão [versão electrónica]. vol.8, n.1, pp. 12-20. ISSN 1645-4464.

[14] Monteiro, M.C.; Costa, M.C. \& Santos, O.(2013). Unidades de Cuidados Continuados Integrados: Uma resposta ao envelhecimento e à dependência em Portugal. Biomed Biopharm Res. Research: Jornal de Investigação Biomédica e Biofarmacêutica, (10) 2:163-178. Disponível em http://www.biomedicalandbiopharmaceuticalresearch.com

[15] RNCCI (2011). Manual do Prestador Recomendações para a melhoria contínua. [versão electrónica]. Acedido a 8 de Março de 2014 em: http://www4.segsocial.pt/documents/10152/3735071/Man Prestador UMCCI-RNCCI

[16] Vaz, M.E. (2001). O quotidiano do idoso esperança ou desesperanças. Revista Intervenção Social, Julho/ 2001. Lisboa, ISSS Departamento Editorial.

[17] MTSS (2011). Carta Social. Rede de Serviços e Equipamentos, Relatório 2011. Acedido a 11 de Março de 2014 em http:// www.cartasocial.pt/pdf/csocial2011.pdf 1/09/2013; ibid. 2013.

[18] Decreto-Lei $\mathrm{n}^{\circ}$ 101/2006, de 6 de Junho. Criação da Rede Nacional de Cuidados Continuados Integrados

[19] Netto, M. P. \& Ponte, J. R. Envelhecimento: desafio na transição do século. In: Papaléo Netto, M. (Coord.) Gerontologia: a velhice e o envelhecimento em visão globalizada. São Paulo: Atheneu; 2002. p.3-12.

[20] Direção Geral da Saúde. (2010). Manual de Boas Práticas para os Assistentes Sociais da Saúde na Rede Nacional de Cuidados Continuados Integrados, Circular normativa $\mathrm{N}^{\mathrm{o}}$ : 29/DSPCS. de 07/07/06. Acedido a 22 de Março de 2013 em http://www.dgs.pt/upload/membro.id/ficheiros/i008206.pdf

[21] UMCSP. (2006). Linhas de Acção Prioritárias para o Desenvolvimento dos Cuidados de Saúde Primários. MCSP/DGS. Acedido em 12/01/2013 em http://www.portaldasaude.pt/NR/rdonlyres/3FADF4DA-34C34F3C-895C-F07AE7AC51A3/2822/linhas ac\% $\% 3 \%$ A7\%C3\%A3o.pdf
[22] RNCCI (2013). Implementação e Monitorização da Rede Nacional de Cuidados Continuados Integrados-Relatório Final. Mar.2013. [versão electrónica]. Acedido a 10 Março 2014 em http://www4.seg-social. pt/documents/10152/3735071/Rel_Imple Monit_RNCCI_2013

[23] Gouveia, M. et al. (2012). Transferências de Cuidados dos Hospitais para Cuidados Primários e Continuados. Faculdade de Medicina da Universidade de Lisboa, Centro de Estudos Aplicados e Centro de Estudos de Medicina Baseada na Evidência da Faculdade de Medicina de Lisboa. Lisboa. [versão electrónica]. Acedido a 22 de Dezembro de 2013 em http://www. aped-dor.com/up/ficheiros-bin2 ficheiro pt_0541251001357131431-58.pdf

[24[ Lin, Chin-Jung et al. (2012) Discharge Planning. International Journal of Gerontology,doi:10.1016/j.jige.2012.05.001

[25] Pompeo, D. et al. Atuação do enfermeiro na alta hospitalar: reflexões a partir dos relatos de pacientes* Acta paul. enferm. [online]. 2007, vol.20, n.3 [citado 2014/03/29], pp 345 350. Disponível em: <http://www.scielo.br/ scielo.php?script $=$ sci_arttext\&pid=S0103 $21002007000300017 \& \operatorname{lng}=\mathrm{en} \& \mathrm{nrm}=\mathrm{iso}>$. ISSN 1982-0194.http://dx.doi.org/10.1590/ S0103-21002007000300017.

[26] Sampieri, R., C. \& Lucio, P. (2006). Metodologia de Pesquisa. São Paulo: McGraw.

[27] José, J,. Wall, K. \& Correia, S. (2002). Trabalhar e cuidar de um idoso dependente: problemas e soluções. Lisboa: Instituto de Ciências Sociais. Universidade de Lisboa.

[28] Tavares, J.P.A.\& Silva, A.L. (2010). Barreiras e soluções nos Cuidados Continuados a pessoas idosas: percepções de Enfermeiros(as). Revista de Enfermagem de Referência. III Série-n ${ }^{\circ} 1$, pp. 17-28.

[29] Carvalho, M. (2005). Uma Abordagem do Serviço Social à Política de Cuidados na Velhice em Portugal. Revista Intervenção Social, 31, 163 - 192.

[30] Grimeer, k. \& Hedges, G.(1999). Staff perceptions of discharge planning: A challenge for quality improvement. Australian Heath Review, Vol 22, n³, pp.25-109 